\title{
139. $\operatorname{In}_{\mathrm{x}} \mathrm{Ga}_{1-\mathrm{x}} \mathrm{N}$ 紫外 LED 励起による $\mathrm{Y}, \mathrm{Sr}, \mathrm{ZnS}$ 系白色蛍光体の発光特性
}

\author{
村上賢司田口常正吉野正彦 \\ (山口大学工学部)（化成オプトニクス）
}

\section{1.はじめに}

近年、窒化物系半導体を用いた短波長発光ダイオードが開発·製品化されたことで、発光ダイオード （Light Emitting Diode : LED）が持つ長寿命・低消費電力・耐衝撃性などの優れた特徴から、電球及び蛍 光灯にかわる照明用光源としての応用が期待されている。

1996 年、 $\mathrm{In}_{\mathrm{x}} \mathrm{Ga}_{1-\mathrm{x}} \mathrm{N}$ を活性層とした青色 LED のチップ上に YAG 蛍光体を塗布した白色 LED が実現 され、チップからの青色光とその青色光の一部により励起された YAG 蛍光体の蛍光との混色により 白色光を実現している。また、1997 年には In を極微量含む $\mathrm{In}_{\mathrm{x}} \mathrm{Ga}_{1-\mathrm{x}} \mathrm{N}$ を活性層とする紫外 LED が開 発され、現在まだ発光強度や外部量子効率は低いものの、この紫外 LED で白色蛍光体を励起すること においても白色光の実現が可能となり、この白色蛍光体からの発光を用いることより高演色の白色光 の実現が期待される。

本研究では $\operatorname{In}_{\mathrm{x}} \mathrm{Ga}_{1-\mathrm{x}} \mathrm{N}$ SQW 構造の紫外 LED で励起した際の各種蛍光体の発光特性の評価と劣化メカ ニズムの検討を行った。

\section{2. 実的と結果}

使用した蛍光体は、広帯域発光型の $\mathrm{ZnS}$ 系白色蛍光体及 び $\mathrm{Eu}$ を添加した $\mathrm{Y}$ 系赤色蛍光体, $\mathrm{ZnS}$ 系緑色蛍光体, $\mathrm{Eu}$ を添加した Sr 系青色営光体を混合して作製した狭帯域発 光型の白色蛍光体 (RGB 白色蛍光体) を用いた。励起用光 源としては、 $\mathrm{In}_{\mathrm{x}} \mathrm{Ga}_{1-\mathrm{x}} \mathrm{N}$ を活性層とする発光波長 $370 \mathrm{~nm}$ の 紫外 LED を用いた。図 1 に紫外 LED で励起した際の ZnS 系白色蛍光体における発光スペクトルの注入電流依存性を 示し、図 2 に紫外 LED で励起した際の RGB 白色蛍光体に おける発光スペクトルの注入電流依存性を示す。これら図 より、どちらの白色蛍光体においても、励起光源である紫 外 LED の注入電流の増加、すなわち励起光強度の増加に伴 うスペクトルの変化が小さいことがわかる。

\section{3. まとめ}

紫外 LED で $\mathrm{Y}, \mathrm{Sr}, \mathrm{ZnS}$ 系蛍光体を励起することにより得 られる白色光スペクトルは、励起光強度の増加に伴うスペ クトルの変化が小さいことから、色度において安定した白 色光を得ることが可能であることがわかった。また、この とき得られた白色光の平均演色評価数 $\mathrm{Ra}$ の值は、 $\mathrm{ZnS}$ 系 白色蛍光体において $\mathrm{Ra}=70 、 \mathrm{RGB}$ 白色蛍光体において $\mathrm{Ra}=83$ であった。以上のことから、紫外 LED で RGB 白色 蛍光体を励起して白色光を得る方式は照明用光源として有 望であるといえる。

\section{[斯辞]}

本研究は MITI/NEDO/JRCM 「高効率電光変換化合物半 導体開発」(通称“21 世紀のあかり”) プロジェクトの援助 を受けて行われたものである。LED の御便宜をはかって頂 きました日亜化学工業の小川英治社長に感謝致します。 Optical property of $\mathrm{Y}, \mathrm{Sr}$ and $\mathrm{ZnS}$-based white phosphor excited by $\operatorname{In}_{\mathrm{x}} \mathrm{Ga}_{1-\mathrm{x}} \mathrm{N}$-based UV LED

K. Murakami, T. Tamura, T. Taguchi and M.Yoshino

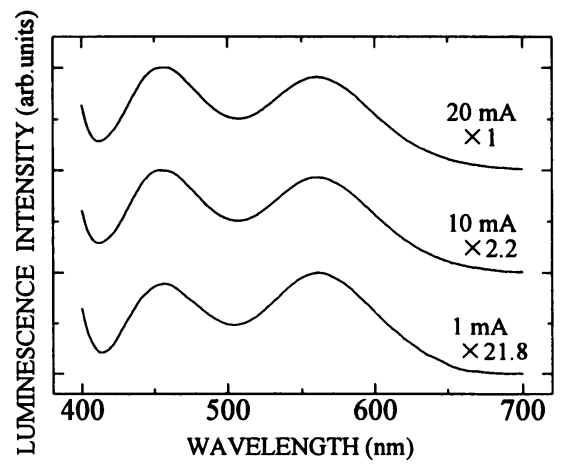

図 $1 . \mathrm{ZnS}$ 系白色蛍光体における発光ス ペクトルの注入電流依存性

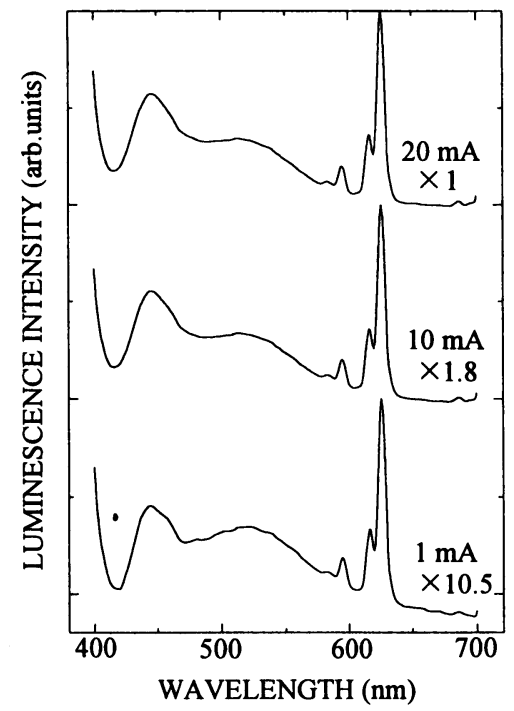

図 2. RGB 白色蛍光体における発光ス ペクトルの注入電流依存性 